\title{
Neutral Charge
}

National Cancer Institute

\section{Source}

National Cancer Institute. Neutral Charge. NCI Thesaurus. Code C81174.

Having no net electric charge; not electrified. 